\title{
The Effect of "MCH Handbook" Utilization Training on Maternal Capability in Early Detecting Development and Stimulating Growth of Children Under the Age of Five Years
}

\author{
Herawati Mansur \\ Health Polytechnic of Malang, Republic of Indonesia
}

\begin{abstract}
One of the purposes of maternal and child health (MCH) program is the autonomy of the family in maintaining maternal and child health. Supposing every mother has a Maternal Child Health (MCH) Handbook and know how to use it, her child health will surely remain supervised. Some reasons for not using MCH Handbook optimally are by virtue of the insuficient knowledge of MCH Handbook utilization and the low educational level. This study aims to asses the effect of MCH Handbook utilization training on maternal capability in early detecting development and stimulating growth of children under the age of five years. Quasi experimental design was opted for this study and the population was 35 mothers of toddlers at the Early Childhood School (ECS) "Garuda" on Malang City. Of the 35 mothers 20 were finally selected as the samples based on the determined criteria. The data were gathered using the interviews and observations (pre and postintervention) and then analyzed using paired sample t-test. The analysis reveals that the maternal capability in early detecting child development at pre-intervention stage was $40 \%$ competent and $60 \%$ incompetent, on the contrary at post-intervention stage $85 \%$ was competent and $15 \%$ was not yet competent. For capability in stimulating child growth at pre-intervention stage, $35 \%$ of the respondents was competent, and $65 \%$ was incompetent, conversely $80 \%$ at post-intervention was competent and $20 \%$ was not yet competent. The analysis on capability in detecting child development reveal the $\quad \boldsymbol{p}$ value of 0.007 mening the training on MCH Handbook utilization took effect on capability in detecting child development. In addition the analysis on respondents capability in stimulating child growth highlightes $p$ value of 0,003 meaning the training on MCH Handbook utilization took effect on the respondents capability in stimulating child growth. It is obvious that MCH Handbbok utilization training is very essential to improve maternal knowledge and skills in order to optimize child growth and development.
\end{abstract}

Keywords: Training, MCH Handbook utilization, early detecting, stimulating

\section{Introduction}

Infancy is so critical in children growth and development that it is very vital for parents to build well foundation in that period. The first years of chidlren life are very crucial for their physical, mental, and psychosocial growth and development and run dramatically so fast that the successes of the first years largely determine their future (Hurlock, 1990). Children are such a precious gift from God that it is indeed compulsory for parents to provide what is necessary for the health, welfare, maintenance, and protection for the puropose of being a devout, healthy, healthy, intelligent, cheerful human useful for himself, family, community, nation, and state. Education is a shared responsibility among families, communities and governments. The family is the first and foremost place of education for children. Children are assumed to have started learning from the conception stage even up to marriage stage. Therefore, the family has a fundamental role in optimizing all children's potential. Bloom from the University of Chicago found a very interesting conclusion about early childhood education. The result showed that $50 \%$ of all human potentials were constructed from conception to the age of toddler. Then $30 \%$ the next potential was shaped at the school age. This means $80 \%$ of basic human potential, how children live after fully grown, was determined mostly at home at preschool age. So, the ability valueing their life, habits, personality and demeanor will $80 \%$ depend on how parents educate them (Wong \& Whaly 1991).

Maternal and child health, taken as a serious problem by the Ministry of Health of the Republic Indonesia, is one of the government programs aimed to reduce maternal mortality rate (MMR) and infant mortality rate (IMR). One of the forceful and sustainable services provided for the objective is through the provision of $\mathrm{MCH}$ handbook to any pregnant woman. $\mathrm{MCH}$ handbooks generally include records of pregnancy and delivery, child development, imunizations and illness, and health education. The handbooks also contain information for mothers on how to properly care for themselves and their children, including pictorial information for illiterate mothers. Thus, the handbooks contain $\mathrm{MCH}$ care records and information for the entire period from pregnancy to early childhood (Depkes, 2009). MCH handbooks are maintained by laypersons at home during antenatal care (ANC), taken to the health service for $\mathrm{MCH}$ records and used up to the baby is five 
years of age. Health officials will record any of $\mathrm{MCH}$ data so that the mother and the family member ascertain about the $\mathrm{MCH}$ condition. One of the purposes of maternal and child health program is the autonomy of the family in maintaining $\mathrm{MCH}$. Mothers and children are mostly vulnerable to various health problems such as pain and nutritional disorders often causing disability or death. $\mathrm{MCH}$ handbook is provided to address this need for the purpose of the autonomy of the family in enabling good health, preventing and addressing the $\mathrm{MCH}$ problem. Supposing every mother has an $\mathrm{MCH}$ handbook and know how to use it, child health will surely ramain monitored. As the $\mathrm{MCH}$ handbook utilization is one of the community empowerment strategies for the family to maintain $\mathrm{MCH}$ and to obtain qualified health services, the district government and municipal authorities must carry out and implement the utilization of MCH Handbook (Depkes, 2009). Two predisposing reasons for mothers not utilizing $\mathrm{MCH}$ Handbook optimally are by virtue of their poor knowledge about its advantages and their low educational level affecting their understanding about the provided information of MCH Handbook (Depkes, 2010).

\section{General Objetive}

To asses the effects of $\mathrm{MCH}$ handbook utilization training on maternal capability in early detecting and stimulating child development.

\section{Specific Objcetives}

1. To identify maternal capability in early detecting development and stimulating growth of children at pre and post-intervention.

2. To analyze the effects of $\mathrm{MCH}$ handbook utilization training on maternal capability in early detecting development and stimulating growth of children.

\section{Contribution of the Study}

The main contribution of this study is as the foundation for policy action plan in order to improve $\mathrm{MCH}$ handbook utilization by mothers for optimizing child development.

\section{Research Design}

\section{Research Methods}

The research was quasi-experimental design with one group pretest-posttest. The main characteristic of one group pre test-post test is to reveal causal relationships by involving a group of subjects in the initial data acquisition (pre-intervention test) and post-intervention test to determine the result of the intervention. The design was as in figure.

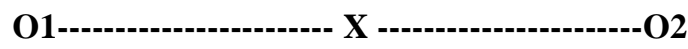

Figure (1): Research Design

Notes:

O1 : Test of the maternal capability in early detecting and stimulating child development under five years of age (pre-intervention)

$\mathrm{X}$ : Treatment "Training on the use MCH Handbook" (intervetion)

O2: Test of the maternal capability in early detecting and stimulating child development under five years of age (post-intervention)

\section{Research Population}

The research population was 35 mothers assisting their children in Early Childhood School (ECS) "Garuda" Tanjung Village, Malang City, East Java Province, Republic of Indonesia.

\section{Samples and Sampling Techniques}

Through the use of purposive sampling, of the 35 mothers 20 were chosen tobe the respondents with the following criteria:

1. Latest education up to Junior High School

2. Does not work (housewife)

3. Have a child aged 1-5 years

4. Never receive any training on early detection of child development

5. Willing to attend training programs.

\section{Research Variables}

Independent variable; Training on $\mathrm{MCH}$ handbook utilization $(\mathrm{X})$. It is a special training about early detection and stimulation on child growth and development through utilization of $\mathrm{MCH}$ Handbook attended by the respondents. 
Dependent variable; The maternal capability in early detecting development and stimulating growth of children (Y). It is the maternal capability to assess children development and stimulate children growth suitable to their age.

\section{Research Hypothesis}

1. There is influence of $\mathrm{MCH}$ handbook utilization training on the maternal capability in early detecting children development.

2. There is influence of $\mathrm{MCH}$ handbook utilization training on the maternal capability in stimulating children growth.

Data Analysis

The descriptive data analysis were used to determine the respondents capability in early detecting development and stimulating growth of children through the following ways:

\section{Early Detection of Children Development}

The respondent was considered competent only if she could perform early detection of the children development of $>50 \%$ of the aspects observed. On the other hand, the respondent was incompetent if the respondent could only detect the development of $\leq 50 \%$ of the aspects observed.

\section{Stimulation of Children Growth}

The respondent was considered competent if she could stimulate children growth of $>50 \%$ of the aspects observed. On the other hand, the respondent was incompetent if the respondent could only stimulate children growth of $\leq 50 \%$ of the aspects observed.The paired sample t-test was used to test the admissibility of the hypothesis of this study.

\section{Result}

Table (1) Distribution of Respondent Characteristics

\begin{tabular}{|l|l|l|}
\hline Age & f & $\%$ \\
\hline$<20$ years & 1 & 5 \\
$20-35$ years & 14 & 70 \\
$>35$ years & 5 & 25 \\
\hline Education & & \\
\hline Junior High School & 14 & 70 \\
Senior High School & 6 & 30 \\
\hline
\end{tabular}

Table (1) shows the average age of respondents ranges from 20-35 years (70\%) and the respondent educational level is mostly junior high school (70\%) and 30\% Senior high school.

Table (2) Distribution of Respondent Capability in Early Detecting and Stimulating at

Pre and Post Intervention

\begin{tabular}{|l|l|l|l|l|l|}
\hline $\begin{array}{l}\text { Capability in Early Detecting Child } \\
\text { Development }\end{array}$ & \multicolumn{2}{l|}{ Pre Intervention } & \multicolumn{2}{l|}{ Post Intervention } \\
\cline { 2 - 6 } & f & \% & f & $\%$ \\
\hline 1 & Competent & 8 & 40 & 17 & 85 \\
\hline 2 & Incompetent & 12 & 60 & 3 & 15 \\
\hline Capability in Stimulating Child Development & & & & \\
\hline 1 & Competent & 7 & 35 & 16 & 80 \\
\hline 2 & Incometent & 13 & 65 & 4 & 20 \\
\hline
\end{tabular}

Table (2) shows before the intervention $40 \%$ of the respondents are competent to perform early detection on children development and $60 \%$ of them are incompetent, whereas after the intervention the number of respondents reaching up the competent category is $85 \%$ and the incompetent respondents dropp down to $15 \%$. In addition the capability capability to provide stimulation before the intervention is $35 \%$ at the competent level and $65 \%$ is incompetent, but after the intervention $80 \%$ of the respondents remarkably reach the competent level and $20 \%$ of them are still incompetent.

Table (3) Results of T-test on Respondent Capability in Early Detecting and Stimulating at Pre and Post-intervention

\begin{tabular}{|l|l|}
\hline Capability in Early Detecting on Children Development & Post - Pre \\
\hline Z & $-2.714 \mathrm{a}$ \\
\hline Asymp. Sig. (2-tailed) & $.007^{*}$ \\
\hline Capability in Stimulating on Children Gowth & \\
\hline Z & $-3.000^{\mathrm{a}}$ \\
\hline Asymp. Sig. (2-tailed) & $.003^{*}$ \\
\hline
\end{tabular}

*Significans at $p<0,01$

The analysis of Table (3) shows the capability to perform detection is at the $\mathrm{p}$ value of 0.007 and for $\mathrm{p}$ $<0.05$, this means the null hypothesis is rejected. In other words there is influence of MCH handbook utilization training on the respondent capability in early detecting children development, while the capability to provide

\begin{tabular}{lll}
\hline DOI: $10.9790 / 1959-0601072025$ & www.iosrjournals.org & $22 \mid$ Page
\end{tabular}


stimulation test results $\mathrm{p}$ value of 0.003 , and for $\mathrm{p}<0.05$, this indicates the null hypothesis is rejected. In conclusion there is influence of $\mathrm{MCH}$ handbook utilization training on the respondent capability in stimulating children growth.

\section{Discussion \\ The effect of MCH handbook utilization training on maternal capability in early detecting children development}

Using the computer program shown on table (3) the conlusion drawn is null hypothesis is rejected and alternative hypothesis is accepted meaning there is influence of MCH handbook utilization training on the respondent capability in early detecting children development.Children go through to distinct period of development. They undergo a process of rapid growth and development fundamental to the next life. They have unique ways of enjoying the world differently from adult. Their prominent characters are active, dynamic, enthusiastic, and curios about what is seen and heard, as if they never stop learning. The role of the mother and other family members in caregiving and bringing them up is very obligatory from newlyborn to preschool. Early detection of child developmental disorders should be attentively taken into account by parents, health workers, trained early childhood teachers, trained kindergarten teachers, doctors, midwives, and nurses utilizing MCH handbook. According Meyrs, children development is an evolutionary process in which children learn from their surrounding in the way of moving, thinking, feeling and relating with others. If during the evolutionary process children get enough stimuli from their surroundings, then they will be able to develop optimally at the following more complex stage, in terms of thinking, feeling and relating positively with others.

A variety of external factors influence early childhood development from conception to preschool. Environmental circumstances and exhanges with key individuals within that environment have significant influence on how each child benefits from each developmental stage.Family circumstances, parents and caregivers will form a pattern of children development from birth. Supportive environments including outdoors, parenting and environmental circumstances will affect the chidlren development up to preschool age. Early childhood years are critical period to experiment, explore, play and be creative without fear of failing to test ideas, learn to solve problems, expand confidence in adulthood, and build relationships with people at the same age. At this time the attention span is expanded and they increase their knowledge (Soetjiningsih, 2006). Parents' role and responsibility on guardianship and child care are obviously enormous, but in reality many parents have not yet possessed a correct understanding of children growth and development. Therefore, through the training on the MCH handbook utilization the maternal knowledge and capability in detecting children growth and development would enhance. The success of the training is also supported by the maturity of the respondents whose age range from $20-35$ years $(\geq 70 \%)$. The higher the maturity level of someone the better critical thinking they have (Narendra, 2002). Hence, the primary goal of the training is to improve positively individual or community health behaviour. It is expected that after attending the MCH handbook utilization training respondent mothers will have more knowledge and ideas about the stimulation and detection of children growth and development. The training is conducted to enhance the knowledge as by having a good knowledge, capabilities will increase as well. In short mother's ability to provide stimulation and detection will be longlasting (Notoatmodjo, 2003).

\section{The effect of the MCH handbook utilization training on respondent capability to provide stimulation on children growth.}

The analysis conducted with the aid of a computer program as shown in table 3.3 reveals that null hypothesis is rejected and alternative hypothesis is accepted meaning there is influence of training on the MCH handbook utilization on the respondent capability in stimulating children growth.Stimulation to infants should be carried out continuously and on every occasion. Mother on baby care is requisite to stimulate her child. The program of Early Childhood Post (ECP) indicate that the parents role to stimualte include their active participation in the organization of Early Childhood Program included presenting the various proposals, joinning childen activities at the Early Childhood Post (ECP) which then to be continued at home, and attending parent coaching activities (parenting) periodically according to the time-period specified. Early Childhood Education program itself aims to maintain and pay attention to facilitate early childhood growth through parenting, educational stimulation, intelligence stimulation, as well as the services of nutrition and health in order to jump-start the intelligence development, therefore, the parents role especially mothers in these activities is absolutely necessary. According Handayani (2003) a working mother would result in lack of quality time between herself and her children, therefore she should be able to spend time with the children to guide, communicate, have fun, and so forth. The same thing to a stay-at-home mother, she should be able to share her time with children as well since it is not all the time certain that a stay-at-home mother ensures her child development from time to time. Handayani (2003) stated that a number of stay-at-home mothers had unfortunately not been able to manage her child relationship and education. She was physically close the child 
but she did not not pay attention to the stimulation needs of her child. In conclusion for both a working mother and a stay-at-home mother the most important aspect of child-rearing is providing sufficient and qualified time to supervise the children development and performing adequate stimulus to them. The stimulation process requires media and learning tools, such as the availability of interactive games suitable to the children age.

Various scientific findings revealed that the human life process from conception to the golden age at the age of 5 years, particularly in the first 2 years was a very critical stage in human development. At this time, the brain growth and development take place dramatically quickly and are profoundly influenced by environmental stimuli, especially qualified caregiving and interactions received by children as well as nutrient intake and health care. It is at their early ages that cognitive, emotional, and social competence start to form and expand. Failure, occured in early childhood especially in the first two years of life, would lead to failure at the later ages which seemed to be permanent and very difficult to restore.

Furthermore, the study also explained that the construction of the brain tissue was going to live only if they were stimulated via various stimuli. Without stimulation or usage, the human brain would not develop quickly because the brain growth had time constraints and the brain stimulation at the early age was totally very important. The delayed stimualtion would cause the brain leisurely responded to new things. Furthermore, Goleman explained that a period of three or four years was a fertile period for the child's brain growth reaching up to more than two-thirds of the adult brain size. During this period, the brain grows to be more complex and faster compared to what would happen afterwards.

Researches on the intelligence show that to maximize the child intelligence, stimulation must have been given since the infancy. The younger the child is given the brain exercises to develop its growth, the smarter he will be later. Brain training started at age 5 might be said to be already late. Brain growth is very fast and rapidly occurs before the age of 1 year. Factually, it is calculated that more than half of the estimated 100.000 cells contained in human genes are used to produce brain cells. Newborns have billions of brain cells which is far more than they are at the age of three years and two times more than the cells of the adult brain. Sensory stimulation can influence brain cell growth and also contribute to making the cells into growing or dying. A baby who never listens to the voices and music, touches things, feels being touched, smells, or sees, over time the brain cells will be weak and die. The education sector emphasizes the stimulation of the intellectual, emotional, spiritual and other supporting aspects.

Environmental stimuli on brain development are a lot more complicated than what we thought. External stimuli affect brain cells in which the nodes connecting the cells regulate how the vertices work and relate to each other. An adult, in his brain, has gray area about the size of a walnut that weighs less than one $\mathrm{kg}$ consisting of billions of brain cells of and trillions of brain nerve knots. This huge number of cells varies depending on how much after the birth the baby gets ample of brain stimulation from the environment. Environmental stimulation works like sculptures that form the barin cells so that the brain can develop properly. Parents and caregivers should be aware of what can and should be doing to make the child enjoy and gain more and more in each stage of child development. To stimulate the children do seem easy, but it takes time. A child needs lots of time and guidance in order to have a positive attitude in learning and getting to know the life (Friedman, 2003).

Games are incentive to maximize brain development so that children grow smarter in various aspects of intelligence. The most important poin is to encourage parents to spend time with joy or challenging games to scaffold children to overcome their problems. The significant effect of $\mathrm{MCH}$ handbook utilization trainning is associated with the easily understood materials provided to expand the insight, knowledge and skills of mothers in terms of providing stimulation and early detection of growth and development for chidlren under five years of age. The training is conducted through the process of communication and exchange of information among health care workers with the target group. The process of communication and information exchange will be effective if it is well planned and uses the appropriate method or suitable media (Sugito, 2007). The research discovered that the level of education and work background of the target group had influence on the comprehension of the messages or information explained, but its influence was not a disturbing factor. Regardless of their low educational level and background their high interest, attention and active participiation in the discussion at the post test proved high.

\section{Conclusion:}

\section{Conclusions and Suggestions}

The conclusions of this study are as follows:

1. There is influence of $\mathrm{MCH}$ handbook utilization training on the respondent capability in early detecting children development. Mothers taking a part in the training received more knowledge, ideas, and discourse applicable for early detection of their children development. In short the goal of the training is to change the behavior of an individual or community health. 
2. There is influence of training on the $\mathrm{MCH}$ handbook utilization on the capability of respondents in stimulating children growth. The training in which the process of communication and information exchange between health care workers and the target group proved effectively incresasing their understanding about the appropriate method or media suitable for stimualtion to children growth and development

\section{Suggestion}

\section{For health care officer}

The results of the research can be beneficial to health services in order to increase the utilization of $\mathrm{MCH}$ Handbook by mothers on baby care in order to optimize children growth and development.

\section{For midwifery education institutions}

Educational institutions should consider the topic on how to prepare maternal child health both early detection and stimulation on children growth and development as the useful prior knowldege for them serving to the community as a midwife.

\section{For research sites}

The results of this study are helpful to improve the capability of respondents, especially in terms of stimulation and early detection of children growth and development.

\section{References}

[1]. Depkes RI. (2009). Buku Kesehatan Ibu dan Anak. Jakarta. Depkes \& JICA.

[2]. Depkes RI. (2009). Petunjuk Tekins Penggunaan Buku Kesehatan Ibu dan Anak. Jakarta. Ditjen Pembinaan Kesehatan Masyarakat.

[3]. Depkes RI. (2010). Pedoman Pelaksanaan Stimulasi, Deteksi dan intervensi Dini Tumbuh Kembang Anak. Jakarta. Ditjen Pembinaan Kesehatan Masyarakat

[4]. Friedman. (2003). Family of nursing: Theory and practice. Connecticut: Appleton \& Lange.

[5]. Handayani, N. M. (2003). Ibu bekerja dan dampaknya bagi perkembangan anak. Diperoleh dari http://info.balitacerdas.com.

[6]. Harlock, E. (1990). Psikologi Perkembangan sepanjang hayat. Jakarta. Erlangga

[7]. Narendra MB. et al. (2002). Tumbuh Kembang Anak dan Remaja edisi pertama. Jakarta. Sagung Seto.

[8]. Notoatmodjo S. (2003). Pendidikan dan Perilaku Kesehatan. Jakarta. Rineka Cipta.

[9]. Soetjiningsih \& Gde Ranuh, I.G.N. (Eds). (2006). Tumbuh Kembang Anak. Jakarta: EGC.

[10]. Sugito. (2007). Pola Asuh Orang Tua dalam Membantu Proses Perkembangan Anak Usia Dini. Makalah Seminar dan Lokakarya Nasional Pendidikan Anak Usia Dini. Yogyakarta. 24 September 2007

[11]. Wong \& Whaley. (1991). Nursing care of Infant's and Children. Tooronto: Musby Company 